CLINICAL STUDY

\title{
Association of variants in gastric inhibitory polypeptide receptor gene with impaired glucose homeostasis in obese children and adolescents from Berlin
}

\author{
Jeannine Sauber, Jessica Grothe, Maria Behm, André Scherag ${ }^{1}$, Harald Grallert ${ }^{2}$, Thomas Illig $^{2}$, Anke Hinney ${ }^{3}$, \\ Johannes Hebebrand ${ }^{3}$, Susanna Wiegand, Annette Grüters, Heiko Krude and Heike Biebermann \\ Institute of Experimental Pediatric Endocrinology, Charité - Universitätsmedizin Berlin, Charité Campus Virchow-Klinikum, Augustenburger Platz 1, \\ 13353 Berlin, Germany, ${ }^{1}$ Institute for Medical Informatics, Biometry and Epidemiology, University of Duisburg-Essen, 45122 Essen, Germany, \\ ${ }^{2}$ Helmholtz Zentrum München - German Research Center for Environmental Health, Institute of Epidemiology, 85764 Neuherberg, Germany and \\ ${ }^{3}$ Department of Child and Adolescent Psychiatry and Psychotherapy, University of Duisburg-Essen, 45147 Essen, Germany
}

(Correspondence should be addressed to H Biebermann; Email: heike.biebermann@charite.de)

\begin{abstract}
Objective: In the past 20 years, obesity has become a major health problem due to associated diseases like type 2 diabetes mellitus. The gastric inhibitory polypeptide receptor (GIPR) modulates body weight and glucose homeostasis and, therefore, represents an interesting candidate gene for obesity and the comorbidity impaired glucose homeostasis. Recently, a GIPR variation was found to be associated with impaired insulin response in humans.

In this study, we screened the GIPR gene for mutations and examined the association between three single-nucleotide polymorphisms (SNPs; rs8111428, rs2302382, rs1800437) and childhood obesity, as well as impaired glucose homeostasis.

Methods: The coding region of the GIPR was screened for mutations by direct sequencing. We genotyped three known SNPs in 2280 healthy normal weight (1696) and obese (584) children and adolescents. Genotyping was performed using the SNaPshot protocol, the iplex, and matrix-assisted laser desorption ionization time-of-flight spectrometry technique. Obesity was defined by a body mass index SDS above 2; homeostatic model assessment was calculated.

Results: No evidence for an association was found between the SNPs and the obesity phenotype. Significant association was found between the minor allele C of the SNP rs1800437 and elevated homeostasis model of insulin resistance values $(P=0.001)$. No further sequence variations in the GIPR were found to be associated with childhood obesity.

Conclusion: Variations of the GIPR sequence are not associated with childhood obesity. This study points to a potential role for rs1800437 in glucose homeostasis. Further studies are necessary to confirm these results.
\end{abstract}

European Journal of Endocrinology 163 259-264

\section{Introduction}

The gastric inhibitory polypeptide (GIP) is a 42 -amino acid incretin released from endocrine $\mathrm{K}$ cells of the duodenum and the small intestine after oral glucose uptake $(1,2)$. Binding to its GIP receptor (GIPR), mainly expressed on the pancreatic $\beta$-cells $(3,4)$, it induces an activation of these cells with an increase in insulin release after meals. GIPR is a member of the G-proteincoupled receptor (GPCR) superfamily, and acts through the activation of adenylyl cyclase (5).

Gipr knockout studies show that GIPR ${ }^{-1-}$ mice are resistant to diet-induced obesity $(3,6)$, and show improved insulin sensitivity in aged GIPR $^{-1-}$ mice compared with wild-type mice (4). High-fat diet-induced obese mice, treated with a GIP antagonist, present a reduction in body weight, triglyceride, and cholesterol levels and an improvement of insulin sensitivity (7). Furthermore, double knockout mice for GIPR and leptin are also resistant to diet-induced obesity (3). Recent studies showed, as well, that vaccination against GIP in mice has a preventive effect for the development of obesity (8). Along with a second incretin glucagon-like peptide 1 (GLP-1), the signaling pathway of GIP represents a target for pharmacological therapies for type II diabetes mellitus as shown in initial studies in mice (9). The role of GIPR single-nucleotide polymorphisms (SNPs) on the glucose and insulin homeostasis was recently shown by identifying a GIPR variant associated with lower 2-h insulin levels in non-diabetic patients (10).

Different association studies of SNPs in the GIPR have been reported so far albeit varying effects of these SNPs were found in association with obese phenotypes in adults $(11,12)$. Based on the assumption, that in 
children the genetic impact on obesity and its comorbidities is higher, we investigated whether two intronic SNPs (rs8111428 and rs2302382), and the exonic rs1800347 (Glu354Gln) of GIPR are associated with severe obesity and elevated homeostasis model assessment values for insulin resistance (HOMA-IR) in children.

Sequencing of GIPR was performed to detect other possible variations within GIPR that might be associated with childhood obesity and impaired glucose homeostasis.

\section{Materials and methods}

\section{Study population}

We examined 2280 children and adolescents aged 2.5-18 years from Berlin. They were either recruited from the obesity outpatient clinic of the 'Sozialpädiatrisches Zentrum' at the Otto-Heubner-Centrum for pediatrics, Charité Berlin $(n=657)$ or from schools as part of the Berlin school children's cohort (BSCOC) conducted at the Institute of Experimental Pediatric Endocrinology at the Charité Berlin $(n=1623)$ (13). No information on the degree of kinship was available for the girls of BSCOC. About $46 \%$ of all recruited children and adolescents had a migratory background with one or both parents not being German. Information on the ethnic background was used to assess whether ethnic differences occurred between the allele frequencies for the three analyzed SNPs. As these analyses provided no evidence for differences in genotypes by selfreported migration background (data not shown), we decided to analyze all data jointly. The purpose of recruiting children was to increase the genetic impact on obesity development, since the time of environmental impact on obesity is reduced compared with adults. To analyze the association between childhood obesity and the SNPs rs8111428, rs2302382, and rs1800437 in and nearby GIPR (Fig. 1), 1696 normal weight or lean and 584 obese children were genotyped. HOMA-IR values were available for a total of 357 of the obese children; among them, sequencing of all 14 exons of GIPR was performed for 87 children to detect further variations that might be associated with obesity.

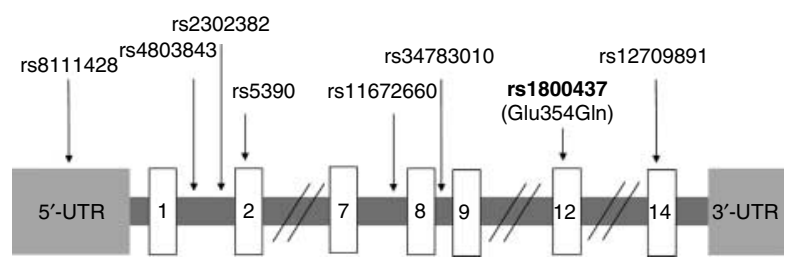

Figure 1 Schematic presentation of the genomic DNA of the GIPR and relative localization of the SNPs analyzed in the association and sequencing study; exons represented as white boxes and numbered; the SNP which shows evidence for an association with HOMA-IR is highlighted.
All patients or their parents gave informed consent. Children with endocrine disorders or syndromal obesity were excluded from the study.

\section{Anthropometric and laboratory measurements}

We examined body weight and body height in 2280 children, clothed in underwear. Body weight was assessed in grams and height in centimeters. The body mass index (BMI)-SDS were calculated using the data from Kromeyer-Hauschild et al. (14). Obesity in childhood and adolescence was defined as BMI-SDS $>2$, which corresponds to the 97.7th gender- and ageadjusted BMI percentile for children (15). This corresponds to the cut-off point proposed by the Childhood Group of the International Obesity Task Force (IOTF) as definition of obesity in children (16). In the analyses, dichotomized BMI-SDS was used as outcome variable. SDS values give a better feasibility of comparison of highly obese children and adolescences (17).

Fasting serum was used for insulin and glucose assessment using commercially available assays. The HOMA-IR was calculated as HOMA = insulin $\times$ glucose/22.5 (mmol/l) (18). The 95th HOMA-IR percentile as estimated by Allard et al. (18) was used to dichotomized HOMA-IR for the analyses (18).

Table 1 summarizes the anthropometric data of the association study population (total sample), and Table 2 summarizes the anthropometric data of the obese children explored in the sequencing study.

\section{SNP analysis and sequencing of GIPR}

DNA was extracted and purified from EDTA blood using a DNA-extracting procedure from Qiagen, or extracted and purified from chewed chewing gum as DNA source using the extracting procedure from Promega.

The GIPR genotype information was downloaded from the International HapMap Project (Build 36.2; www.hapmap.org) according to which, all three SNPs had a minor allele frequency larger than 5\% in the CEU (Utah residents with Northern and Western European ancestry from the CEPH collection) population.

Subjects were either genotyped using the SNaPshot technique from Applied Biosystems (Darmstadt, Germany), or using the matrix-assisted laser desorption ionization time-of-flight spectrometry (MALDI-TOF) from Sequenom (Hamburg, Germany). The calling rate was $98.8 \%$ for rs $8111428,98.3 \%$ for rs 2302382 , and $97.4 \%$ for rs 1800437 . PCR was done for the 14 exons and the intron/exon boundaries, using primers assessed by Primer3 (19). GIPR was sequenced using an ABI 3130xl capillary DNA sequencer (Applied Biosystems). Except for rs1800437, no evidence for deviations from Hardy-Weinberg equilibrium (HWE) was detected (all $P \gg 0.10)$. However, we observed evidence for deviations from HWE from rs1800437 in the obese 
Table 1 Anthropometric variables of the association study population.

\begin{tabular}{lcccc}
\hline Group & $\begin{array}{c}\text { No. of } \\
\text { participants }\end{array}$ & $\begin{array}{c}\text { Sex } \\
(\mathrm{M} / \mathrm{F})\end{array}$ & $\begin{array}{c}\text { Mean age } \\
\text { (years) } \pm \text { s.D. }\end{array}$ & $\begin{array}{c}\text { Mean BMI-SDS } \\
\left(\mathrm{kg} / \mathrm{m}^{2}\right) \pm \text { s.D. }\end{array}$ \\
\hline Normal weight or lean children & 1696 & $65 / 1631$ & $12.31 \pm 2.30$ & $0.04 \pm 0.95$ \\
Obese children & 584 & $236 / 348$ & $10.95 \pm 3.56$ & $2.80 \pm 0.53$ \\
\hline
\end{tabular}

children $(P=0.03)$ and in both HOMA-IR groups $(P=0.05$ and $P=0.005)$. Most likely, these deviances also indicate the genetic association with HOMA-IR, which we observed.

\section{Statistical analysis}

All statistical analyses were performed using the SPSS 17 program (Munchen, Germany). All genotype distributions were explored for deviations from HWE using an exact test. The dichotomized BMI-SDS and the HOMA-IR data were also analyzed by an exact version of Pearson's $\chi^{2}$ test for $2 \times 3$ tables. The significance level of each test was set to $\alpha=0.05$ (two-sided). We applied no correction for multiple testing, and all $P$ values reported are two-sided.

\section{Results}

We analyzed the association of genetic variants in the GIPR with childhood obesity and dichotomized HOMAIR. No evidence for an association could be found between obesity and the three analyzed SNPs rs8111428, rs2302382, and rs1800437. Though, we observed that the A-allele of the SNP rs2302382 was descriptively more often present in obese children than in normal weight or lean children (Table 3).

However, evidence for an association was found between the minor allele C of the SNP rs1800437 and increased dichotomized HOMA-IR values (odds ratio

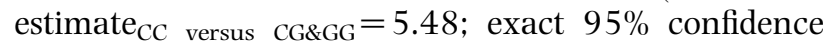
interval 1.73...22.80; $P=0.001$; Table 4).

For sensitivity analyses, we performed stratified analyses by ethnicity and gender. We observed no large impact on the reported genetic association with obesity and dichotomized HOMA-IR (data not shown). Independent of genotype, however, we were able to replicate the known higher frequency of obesity in German children of Arabian and the Turkish ethnicity $(20,21)$ when compared with children of German ethnicity. This difference in obesity prevalence was also observable for HOMA-IR. For 357 of the children and adolescents, a HOMA-IR value was assessed with $47.1 \%$ of the children having a HOMA-IR value above the 95 th percentile according to Allard et al.; a total of $74.5 \%$ of the children with HOMA-IR values below the 95th percentile were of German origin, whereas only $59.2 \%$ of the children above the 95th percentile were of German origin. Nevertheless, the ethnical mixture of the population studied does not seem to bias the results as no significant differences between the allele frequencies could be detected for the three SNPs analyzed in the HOMA-IR study in children and adolescents of German and Turkish origin. Furthermore, all children, for whom HOMA-IR values were assessed, were obese, regardless of their ethnicity. Unfortunately, it was only possible to achieve meaningful evaluations for German and Turkish children and adolescents because the sample number was too low for the other ethnical groups. In the HOMA-IR study group, the German children and adolescents had a mean BMI-SDS of 2.82, and children and adolescents of Turkish origin had a mean BMI-SDS of 2.93. In addition, the children and adolescents analyzed in our study do not show any significant difference in terms of BMI between the two groups, HOMA-IR values below (mean BMI-SDS = 2.78) and above the 95th percentile (mean BMI-SDS=2.95). Therefore, even if Turkish children are generally more prone to obesity, our study group was homogeneous in terms of BMI, and we finally decided to integrate all children and adolescents in the calculation, independently of their ethnical background. In terms of other factors, such as the socio-economical status, we could not make any reliable statements due to a lack of sufficient information.

In the sequencing study, a total of five SNPs, rs4803845, rs5390, rs12709891, rs11672660, and rs34783010 (Fig. 1) were detected among 87 children (Table 5). All variants were found in non-coding regions of the GIPR and were already known from the HapMap database. None of the variations showed evidence for an association with childhood obesity. Though, some evidence for a potential association of the A-allele with elevated HOMA-IR levels was provided for the SNP rs12709891 $(P=0.069)$. Furthermore, we detected the variation Tyr240His in exon 8 , which occurred in one normal weight child with normal HOMA-IR level but

Table 2 Anthropometric variables of the study groups for the sequencing study.

\begin{tabular}{lccrr}
\hline Group & $\begin{array}{c}\text { No. of } \\
\text { participants }\end{array}$ & $\begin{array}{l}\text { Sex } \\
(\mathrm{M} / \mathrm{F})\end{array}$ & $\begin{array}{c}\text { Mean age } \\
(\text { years }) \pm \text { s.D. }\end{array}$ & $\begin{array}{r}\text { Mean BMI-SDS } \\
\left(\mathrm{kg} / \mathrm{m}^{2}\right) \pm \text { S.D. }\end{array}$ \\
\hline HOMA-IR $<95$ th percentile & 37 & $16 / 21$ & $9.72 \pm 2.92$ & $2.22 \pm 0.72$ \\
HOMA-IR $\geq 95$ th percentile & 50 & $23 / 27$ & $13.09 \pm 2.29$ & $2.78 \pm 0.58$ \\
\hline
\end{tabular}


Table 3 Genotype and allele frequencies for normal weight or lean and obese children for the three analyzed single-nucleotide polymorphisms (SNPs).

\begin{tabular}{|c|c|c|c|c|c|c|c|}
\hline \multirow{3}{*}{$\frac{\text { SNP }}{\text { rs8111428 }}$} & \multirow{3}{*}{\begin{tabular}{l}
\multicolumn{1}{c}{ Group } \\
Obese children \\
Normal weight or lean children
\end{tabular}} & \multicolumn{3}{|c|}{ Genotypes, $\boldsymbol{n}$ (frequency) } & \multicolumn{2}{|c|}{ Frequency of allele } & \multirow{2}{*}{$\frac{P \text { value }}{0.526}$} \\
\hline & & $367(0.630)$ AA & $192(0.330) \mathrm{AG}$ & $22(0.038) \mathrm{GG}$ & & $0.200 \mathrm{G}$ & \\
\hline & & $1088(0.650) A A$ & 513 (0.228) AG & $72(0.032) \mathrm{G}($ & 0.810 & 0.19 & \\
\hline rs2302382 & $\begin{array}{l}\text { Obese children } \\
\text { Normal weight or lean children }\end{array}$ & $\begin{array}{l}349(0.602) \mathrm{CC} \\
1031(0.620) \mathrm{CC}\end{array}$ & $\begin{array}{l}202(0.348) A C \\
547(0.329) A C\end{array}$ & $\begin{array}{l}29(0.050) \mathrm{AA} \\
84(0.037) \mathrm{AA}\end{array}$ & $\begin{array}{l}0.776 \mathrm{C} \\
0.785 \mathrm{C}\end{array}$ & $\begin{array}{l}0.224 \mathrm{~A} \\
0.215 \mathrm{~A}\end{array}$ & 0.696 \\
\hline rs1800437 & $\begin{array}{l}\text { Obese children } \\
\text { Normal weight or lean children }\end{array}$ & $\begin{array}{l}344(0.616) \mathrm{GG} \\
984(0.592) \mathrm{GG}\end{array}$ & $\begin{array}{l}180(0.323) \mathrm{CG} \\
571(0.344) \mathrm{CG}\end{array}$ & $\begin{array}{l}34(0.061) \mathrm{CC} \\
107(0.064) \mathrm{CC}\end{array}$ & $\begin{array}{l}0.778 \mathrm{G} \\
0.764 \mathrm{G}\end{array}$ & $\begin{array}{l}0.222 \mathrm{C} \\
0.236 \mathrm{C}\end{array}$ & 0.589 \\
\hline
\end{tabular}

severely increased triglyceride levels. As the two sisters of this child were obese but do not carry the mutation, no further studies of this variant were performed to examine the association with obesity and impaired insulin sensitivity.

\section{Discussion}

So far, the role of genetic variations within the GIPR gene for different phenotypes like obesity and glucose metabolism remains controversial $(12,13)$, though physiological studies $(3,5,9)$ clearly demonstrated the important role of the GIPR in weight regulation and glucose homeostasis.

We found evidence for a significant association between the minor allele of the exonic SNP rs1800437 of the GIPR and an elevated HOMA-IR value (above the 95th percentile) in these children and adolescents. The presence of the minor allele $\mathrm{C}$ induces an exchange from the amino acid glutamate to glutamine in transmembrane domain six (TM6; Fig. 2). Functional studies analyzing the impact of the amino acid exchange induced by rs1800437 on receptor function have not been published so far. However, naturally occurring mutations in other GPCRs, like the TSH receptor, indicate that the TM6 is highly susceptible for constitutive activation (22). Consistent with these data, one study reported an artificial activating mutation Thr340Pro in TM6 of the GIPR, which leads to an increase in basal cAMP compared with the wild-type receptor (23) (Fig. 2). Taking these observations together, we hypothesize that a constitutive activation of the GIPR by a variant in TM6 is conceivable.

As shown by several previous studies, Gipr knockout mice showed improved insulin sensitivity, and mice treated with GIP antagonists had lower insulin levels $(2,4,5)$. Therefore, loss of function of the GIPR would lead to a better insulin homeostasis capacity. An association between the SNP rs1800437 and a pathological HOMA-IR, which indicates an impaired glucose homeostasis prior to the manifestation of diabetes, may therefore be explained by gain of function effect implicated by the minor allele of this SNP on the GIPR.

To be sure, functional characterizations of the variant are necessary. Though the functional characterization of rs1800437 might be difficult to assess yet, since its effect on cAMP increase might be very small. Lessons can be learned from other GPCRs as for example, the melanocortin-4 receptor gene (MC4R) variant Val103Ile, which leads to a slight but significant and robustly replicated decreased body weight in individuals carrying the minor allele (103Ile) of this SNP $(24,25)$. Functional studies of Val103Ile, however, could only detect a marginal effect in response to inverse agonist challenge (26), whereas other functional studies failed to demonstrate a difference between cAMP levels in wild-type and in Val103Ile MC4R $(25,27)$. A possible explanation for this apparent discrepancy are very small individual effects at the functional level that are yet undetectable by the given study designs, which can nevertheless have an impact on the clinical phenotype if present for a longer period of time (28). In the case of inactivating variations within GIPR, a smaller effect on the phenotype expression might be accentuated by the complementary role of the incretin GLP-1 and its receptor $(7,29)$. GLP-1 and GIP seem to share a common pathway in the $\beta$-cell, which results in insulin release under feeding conditions. However, in the case of variations leading to constitutive activation of GIPR, the receptor effect of the activated GIPR is present in fasting state without ligand binding as both incretins are only secreted after nutrient intake.

Table 4 Allele frequency of the single-nucleotide polymorphisms (SNPs) rs8111428, rs2302382, and rs1800437 and the homeostasis model assessment values for insulin resistance (HOMA-IR) status.

\begin{tabular}{|c|c|c|c|c|c|c|c|}
\hline \multirow{2}{*}{$\frac{\text { SNP }}{\text { rs8111428 }}$} & \multirow{2}{*}{$\begin{array}{c}\text { Group } \\
\text { HOMA-IR }<95 \text { th percentile } \\
\text { HOMA-IR } \geq 95 \text { th percentile }\end{array}$} & \multicolumn{3}{|c|}{ Genotypes, $\boldsymbol{n}$ (frequency) } & \multicolumn{2}{|c|}{ Frequency of allele } & \multirow{2}{*}{$\frac{P \text { value }}{0.923}$} \\
\hline & & $\begin{array}{l}116 \text { (0.614) AA } \\
106(0.639) A A\end{array}$ & $\begin{array}{l}66(0.349) \mathrm{AG} \\
54(0.325) \mathrm{AG}\end{array}$ & & & & \\
\hline rs2302382 & $\begin{array}{l}\text { HOMA-IR }<95 \text { th percentile } \\
\text { HOMA-IR } \geq 95 \text { th percentile }\end{array}$ & $\begin{array}{l}111(0.587) \mathrm{CC} \\
105(0.633) \mathrm{CC}\end{array}$ & $\begin{array}{l}71(0.376) \text { AC } \\
52(0.313) \text { AC }\end{array}$ & $\begin{array}{l}7(0.037) \mathrm{AA} \\
9(0.054) \mathrm{AA}\end{array}$ & $\begin{array}{l}0.775 \mathrm{C} \\
0.789 \mathrm{C}\end{array}$ & $\begin{array}{l}0.225 \mathrm{~A} \\
0.215 \mathrm{~A}\end{array}$ & 0.396 \\
\hline rs1800437 & $\begin{array}{l}\text { HOMA-IR }<95 \text { th percentile } \\
\text { HOMA-IR } \geq 95 \text { th percentile }\end{array}$ & $\begin{array}{l}106(0.582) \mathrm{GG} \\
92(0.594) \mathrm{GG}\end{array}$ & $\begin{array}{l}72(0.396) \mathrm{CG} \\
46(0.297) \mathrm{CG}\end{array}$ & $\begin{array}{l}4(0.022) \mathrm{CC} \\
17(0.110) \mathrm{CC}\end{array}$ & $\begin{array}{l}0.780 \mathrm{G} \\
0.741 \mathrm{G}\end{array}$ & $\begin{array}{l}0.220 \mathrm{C} \\
0.259 \mathrm{C}\end{array}$ & 0.001 \\
\hline
\end{tabular}


Table 5 Variations found by sequencing GIPR in 87 children with known homeostasis model assessment values for insulin resistance (HOMA-IR) levels.

\begin{tabular}{|c|c|c|c|c|c|c|c|}
\hline \multirow{2}{*}{$\frac{\text { SNP }}{\text { rs4803845 }}$} & \multirow{3}{*}{$\begin{array}{c}\text { Group } \\
\text { HOMA-IR }<95 \text { th percentile } \\
\text { HOMA-IR } \geq 95 \text { th percentile }\end{array}$} & \multicolumn{3}{|c|}{ Genotypes, $\boldsymbol{n}$ (frequency) } & \multicolumn{2}{|c|}{ Frequency of allele } & \multirow{2}{*}{$\frac{\boldsymbol{P} \text { value }}{0.198^{\mathrm{a}}}$} \\
\hline & & $37(1.000) \mathrm{CC}$ & $0(0.000) \mathrm{CT}$ & $0(0.000) \mathrm{TT}$ & $1.000 \mathrm{C}$ & $0.000 \mathrm{~T}$ & \\
\hline & & $50(1.000) \mathrm{CC}$ & $0(0.000) \mathrm{CT}$ & $0(0.000)$ TT & $1.000 \mathrm{C}$ & $0.000 \mathrm{~T}$ & \\
\hline \multirow[t]{2}{*}{ rs5390 } & HOMA-IR $<95$ th percentile & $36(0.973) \mathrm{CC}$ & $1(0.270) \mathrm{CG}$ & $0(0.000) \mathrm{GG}$ & $0.986 \mathrm{C}$ & $0.014 \mathrm{G}$ & 0.495 \\
\hline & HOMA-IR $\geq 95$ th percentile & $49(0.980) \mathrm{CC}$ & $1(0.020) \mathrm{CG}$ & $0(0.000) \mathrm{GG}$ & $0.990 \mathrm{C}$ & $0.010 \mathrm{G}$ & \\
\hline \multirow[t]{2}{*}{ rs12709891 } & HOMA-IR $<95$ th percentile & $37(1.000) \mathrm{CC}$ & $0(0.000) \mathrm{CA}$ & $0(0.000) \mathrm{AA}$ & $1.000 \mathrm{C}$ & $0.000 \mathrm{~A}$ & 0.069 \\
\hline & HOMA-IR $\geq 95$ th percentile & $45(0.900) \mathrm{CC}$ & $5(0.100) \mathrm{CA}$ & $0(0.000) \mathrm{AA}$ & $0.950 \mathrm{C}$ & $0.050 \mathrm{~A}$ & \\
\hline \multirow{2}{*}{ rs11672660 } & HOMA-IR $<95$ th percentile & $22(0.595) \mathrm{CC}$ & $14(0.378) \mathrm{CT}$ & $1(0.027) \mathrm{TT}$ & $0.783 \mathrm{C}$ & $0.217 \mathrm{~T}$ & 0.564 \\
\hline & HOMA-IR $\geq 95$ th percentile & $32(0.640) \mathrm{CC}$ & $18(0.360) \mathrm{CT}$ & $0(0.000)$ TT & $0.820 \mathrm{C}$ & $0.180 \mathrm{~T}$ & \\
\hline \multirow[t]{2}{*}{ rs34783010 } & HOMA-IR $<95$ th percentile & 24 (0.649) GG & $12(0.324) \mathrm{GT}$ & $1(0.027) \mathrm{TT}$ & $0.810 \mathrm{G}$ & $0.190 \mathrm{~T}$ & 0.439 \\
\hline & HOMA-IR $\geq 95$ th percentile & $36(0.720) \mathrm{GG}$ & $14(0.280) \mathrm{GT}$ & $0(0.000)$ TT & $0.860 \mathrm{G}$ & $0.140 \mathrm{~T}$ & \\
\hline
\end{tabular}

${ }^{\mathrm{a}}$ For a binomial test.

Regarding their role for childhood and adolescence obesity, neither the three analyzed SNPs nor the five variants detected by sequencing provided evidence for a genetic association. Most likely, given the small genetic effect sizes reported for obesity so far (30), the power of our study has been too small to detect obesity effects related to these SNPs. So far, an association between variants in GIPR and obesity cannot be completely ruled out. Further investigation in much larger samples will be required to finally unravel the impact of GIPR as a gene for obesity.

Our findings concerning the role of GIPR as a candidate gene for insulin impairment are supported by the "Meta-Analyses of Glucose and Insulin-related traits Consortium' (MAGIC) (10): very recently, within the scope of a meta-analysis of the MAGIC, Saxena et al. identified a variation in the GIPR (rs10423928) to be associated with increased 2-h glucose and an impaired insulin response on glucose challenge during oral glucose tolerance test. Additionally, this SNP is in strong linkage disequilibrium (LD) with the SNP rs1800437 showing association with elevated HOMA-IR levels in children. Both SNPs have an effect on the glucose homeostasis (10).

In sum, though this study could not provide evidence for a genetic association of all eight analyzed variants to

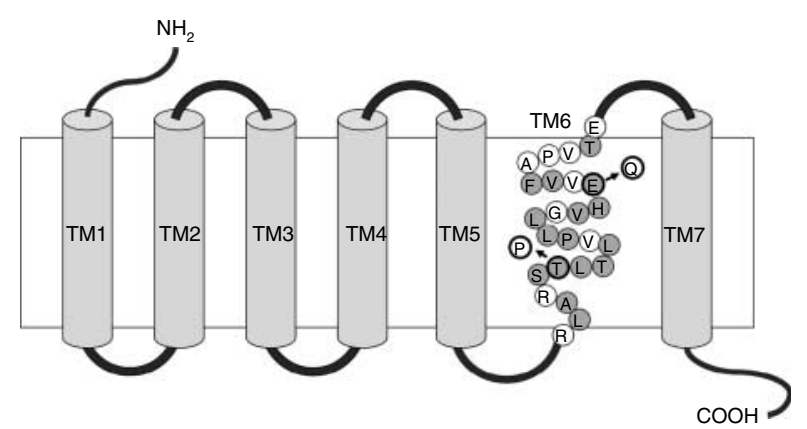

Figure 2 Schematic structure of the GIPR with transmembrane domain 6 (TM6) in detail; activating variants highlighted: rs1800437 (Glu354GIn; $\mathrm{E} \rightarrow \mathrm{Q}$ ) and the artificial variant Thr340Pro $(T \rightarrow P)$; relative localization of activating TSHR mutations in gray (according to http://www.ssfa-gphr.de/natural_ali.php) (31). childhood and adolescence obesity, the role of GIPR as a candidate gene for insulin impairment is strengthened as we observed evidence for an association of the exonic SNP rs1800437 and the elevated HOMA-IR values in a relatively small sample of only 357 children and as this SNP is in strong LD with another GIPR variation showing an effect on insulin secretion.

\section{Declaration of interest}

The authors declare that there is no conflict of interest that could be perceived as prejudicing the impartiality of the research reported.

\section{Funding}

This work was financially supported by the DFG funded Graduate College 1208 (TP1) and the NGFN Plus 01GS0820, 01GS0823, and 01GS0825.

\section{Acknowledgements}

We thank Sabine Jyrch for her experimental assistance and Ingrid Rehwald for anthropometric measurements.

\section{References}

1 Yip RG \& Wolfe MM. GIP biology and fat metabolism. Life Sciences 200066 91-103.

2 Rudovich N, Kaiser S, Engeli S, Osterhoff M, Gogebakan O, Bluher M \& Pfeiffer AF. GIP receptor mRNA expression in different fat tissue depots in postmenopausal non-diabetic women. Regulatory Peptides $2007142138-145$.

3 Miyawaki K, Yamada Y, Ban N, Ihara Y, Tsukiyama K, Zhou H, Fujimoto S, Oku A, Tsuda K, Toyokuni S, Hiai H, Mizunoya W, Fushiki T, Holst JJ, Makino M, Tashita A, Kobara Y, Tsubamoto Y, Jinnouchi T, Jomori T \& Seino Y. Inhibition of gastric inhibitory polypeptide signaling prevents obesity. Nature Medicine 20028 $738-742$.

4 Yamada Y \& Seino Y. Physiology of GIP - a lesson from GIP receptor knockout mice. Hormone and Metabolic Research 200436 771-774.

5 Getty-Kaushik L, Song DH, Boylan MO, Corkey BE \& Wolfe MM. Glucose-dependent insulinotropic polypeptide modulates adipocyte lipolysis and reesterification. Obesity 200614 1124-1131.

6 McClean PL, Irwin N, Cassidy RS, Holst JJ, Gault VA \& Flatt PR. GIP receptor antagonism reverses obesity, insulin resistance, and associated metabolic disturbances induced in mice by prolonged consumption of high-fat diet. American Journal of Physiology. Endocrinology and Metabolism 2007293 E1746-E1755. 
7 Hansotia T, Maida A, Flock G, Yamada Y, Tsukiyama K, Seino Y \& Drucker DJ. Extrapancreatic incretin receptors modulate glucose homeostasis, body weight, and energy expenditure. Journal of Clinical Investigation $2007 \mathbf{1 1 7} 143-152$.

8 Fulurija A, Lutz TA, Sladko K, Osto M, Wielinga PY, Bachmann MF \& Saudan P. Vaccination against GIP for the treatment of obesity. PLoS ONE 20083 e3163.

9 Irwin N, McClean PL, Cassidy RS, O’Harte FP, Green BD, Gault VA, Harriott P \& Flatt PR. Comparison of the anti-diabetic effects of GIP- and GLP-1-receptor activation in obese diabetic (ob/ob) mice: studies with DPP IV resistant N-AcGIP and exendin(1-39)amide. Diabetes/Metabolism Research and Reviews $200723572-579$.

10 Saxena R, Hivert MF, Langenberg C, Tanaka T, Pankow JS, Vollenweider P, Lyssenko V, Bouatia-Naji N, Dupuis J, Jackson AU, Kao WH, Li M, Glazer NL, Manning AK, Luan J, Stringham HM, Prokopenko I, Johnson T, Grarup N, Boesgaard TW, Lecoeur C, Shrader P, O'Connell J, Ingelsson E, Couper DJ, Rice K, Song K, Andreasen CH, Dina C, Kottgen A, Le Bacquer O, Pattou F, Taneera J, Steinthorsdottir V, Rybin D, Ardlie K, Sampson M, Qi L, van Hoek M, Weedon MN, Aulchenko YS, Voight BF, Grallert H, Balkau B, Bergman RN, Bielinski SJ, Bonnefond A, Bonnycastle LL, Borch-Johnsen K, Bottcher Y, Brunner E, Buchanan TA, Bumpstead SI, Cavalcanti-Proenca C, Charpentier G, Chen YD, Chines PS, Collins FS, Cornelis M, Crawford JG, Delplanque J, Doney A, Egan JM, Erdos MR, Firmann M, Forouhi NG, Fox CS, Goodarzi MO, Graessler J, Hingorani A, Isomaa B, Jorgensen T, Kivimaki M, Kovacs P, Krohn K, Kumari M, Lauritzen T, LevyMarchal C, Mayor V, McAteer JB, Meyre D, Mitchell BD, Mohlke KL, Morken MA, Narisu N, Palmer CN, Pakyz R, Pascoe L, Payne F, Pearson D, Rathmann W, Sandbaek A, Sayer AA, Scott LJ, Sharp SJ, Sijbrands E, Singleton A, Siscovick DS, Smith NL, Sparso T, Swift AJ, Syddall H, Thorleifsson G, Tonjes A, Tuomi T, Tuomilehto J, Valle TT, Waeber G, Walley A, Waterworth DM, Zeggini E, Zhao JH, Illig T, Wichmann HE, Wilson JF, van Duijn C, Hu FB, Morris AD, Frayling TM, Hattersley AT, Thorsteinsdottir U, Stefansson K, Nilsson P, Syvanen AC, Shuldiner AR, Walker M, Bornstein SR, Schwarz P, Williams GH, Nathan DM, Kuusisto J, Laakso M, Cooper C, Marmot M, Ferrucci L, Mooser V, Stumvoll M, Loos RJ, Altshuler D, Psaty BM, Rotter JI, Boerwinkle E, Hansen T, Pedersen O, Florez JC, McCarthy MI, Boehnke M, Barroso I, Sladek R, Froguel P, Meigs JB, Groop L, Wareham NJ \& Watanabe RM. Genetic variation in GIPR influences the glucose and insulin responses to an oral glucose challenge. Nature Genetics 201042 142-148.

11 Nitz I, Fisher E, Weikert C, Burwinkel B, Li Y, Mohlig M, Boeing H, Schreiber S, Schrezenmeir J \& Doring F. Association analyses of GIP and GIPR polymorphisms with traits of the metabolic syndrome. Molecular Nutrition \& Food Research 200751 1046-1052.

12 Vogel CI, Scherag A, Bronner G, Nguyen TT, Wang HJ, Grallert H, Bornhorst A, Rosskopf D, Volzke H, Reinehr T, Rief W, Illig T, Wichmann HE, Schafer H, Hebebrand J \& Hinney A. Gastric inhibitory polypeptide receptor: association analyses for obesity of several polymorphisms in large study groups. BMC Medical Genetics 20091019.

13 Bau AM, Ernert A, Schenk L, Wiegand S, Martus P, Gruters A \& Krude $\mathrm{H}$. Is there a further acceleration in the age at onset of menarche? A cross-sectional study in 1840 school children focusing on age and bodyweight at the onset of menarche European Journal of Endocrinology 2009160 107-113.

14 Kromeyer-Hauschild K, Wabitsch M, Kunze D, Geller F, Geib HC, Hesse V, von Hippel A, Jaeger U, Johnsen D, Korte W, Menner K, Müller G, Müller JM, Niemann-Pilatus A, Remer T, Schaefer F, Wittchen HU, Zabransky S, Zellner K, Ziegler A \& Hebebrand J. Perzentile für den Bodymass-Index für das Kindes- und Jugendalter unter Heranziehung verschiedener deutscher Stichproben. Monatsschrift für Kinderheilkunde 2001149 807-818.

15 Cole TJ. The LMS method for constructing normalized growth standards. European Journal of Clinical Nutrition $19904 \mathbf{4 4 5 - 6 0 .}$
16 Cole TJ, Bellizzi MC, Flegal KM \& Dietz WH. Establishing a standard definition for child overweight and obesity worldwide: international survey. BMJ $2000 \mathbf{3 2 0} 1240-1243$.

17 Wabitsch M \& Moß A. Evidenzbasierte Leitlinie der Arbeitsgemeinschaft Adipositas im Kindes- und Jugendalter und der beteiligten medizinischen-wissenschaftlichen Fachgesellschaften, Berufsverbände und weitere Organisationen.: Arbeitsgemeinschaft Adipositas im Kindes- und Jugendalter (AGA) www. a-g-a.de, 2009.

18 Allard P, Delvin EE, Paradis G, Hanley JA, O'Loughlin J, Lavallee C, Levy E \& Lambert M. Distribution of fasting plasma insulin, free fatty acids, and glucose concentrations and of homeostasis model assessment of insulin resistance in a representative sample of Quebec children and adolescents. Clinical Chemistry $200349644-649$.

19 Rozen S \& Skaletsky H. Primer3 on the WWW for general users and for biologist programmers. Methods in Molecular Biology 2000 132 365-386.

20 Moss A, Wabitsch M, Kromeyer-Hauschild K, Reinehr T \& Kurth BM. Prevalence of overweight and adiposity in German school children. Bundesgesundheitsblatt, Gesundheitsforschung, Gesundheitsschutz $2007 \mathbf{5 0} 1424-1431$.

21 Ozer BK. Growth reference centiles and secular changes in Turkish children and adolescents. Economics and Human Biology 20075 280-301.

22 Smit MJ, Vischer HF, Bakker RA, Jongejan A, Timmerman H, Pardo L \& Leurs R. Pharmacogenomic and structural analysis of constitutive g protein-coupled receptor activity. Annual Review of Pharmacology and Toxicology 2007 47 53-87.

23 Tseng CC \& Lin L. A point mutation in the glucose-dependent insulinotropic peptide receptor confers constitutive activity. Biochemical and Biophysical Research Communications 1997232 96-100.

24 Geller F, Reichwald K, Dempfle A, Illig T, Vollmert C, Herpertz S, Siffert W, Platzer M, Hess C, Gudermann T, Biebermann H, Wichmann HE, Schafer H, Hinney A \& Hebebrand J. Melanocortin-4 receptor gene variant $\mathrm{I} 103$ is negatively associated with obesity. American Journal of Human Genetics 200474 572-581.

25 Xiang Z, Litherland SA, Sorensen NB, Proneth B, Wood MS, Shaw AM, Millard WJ \& Haskell-Luevano C. Pharmacological characterization of 40 human melanocortin- 4 receptor polymorphisms with the endogenous proopiomelanocortin-derived agonists and the agouti-related protein (AGRP) antagonist. Biochemistry $2006 \mathbf{4 5} 7277-7288$.

26 Rosmond R, Chagnon M, Bouchard C \& Bjorntorp P. A missense mutation in the human melanocortin- 4 receptor gene in relation to abdominal obesity and salivary cortisol. Diabetologia $2001 \mathbf{4 4}$ 1335-1338.

27 Gu W, Tu Z, Kleyn PW, Kissebah A, Duprat L, Lee J, Chin W, Maruti S, Deng N, Fisher SL, Franco LS, Burn P, Yagaloff KA, Nathan J, Heymsfield S, Albu J, Pi-Sunyer FX \& Allison DB. Identification and functional analysis of novel human melanocortin-4 receptor variants. Diabetes $1999 \mathbf{4 8} 635-639$.

28 Heid IM, Vollmert C, Kronenberg F, Huth C, Ankerst DP, Luchner A, Hinney A, Bronner G, Wichmann HE, Illig T, Doring A \& Hebebrand J. Association of the MC4R V103I polymorphism with the metabolic syndrome: the KORA Study. Obesity 200816 369-376.

29 Tseng CC, Zhang XY \& Wolfe MM. Effect of GIP and GLP-1 antagonists on insulin release in the rat. American Journal of Physiology 1999276 E1049-E1054.

30 Walley AJ, Asher JE \& Froguel P. The genetic contribution to nonsyndromic human obesity. Nature Reviews. Genetics 2009 10431-442.

31 Kleinau G, Brehm M, Wiedemann U, Labudde D, Leser U \& Krause G. Implications for molecular mechanisms of glycoprotein hormone receptors using a new sequence-structure-function analysis resource. Molecular Endocrinology 200721 574-580.

Received 7 May 2010

Accepted 1 June 2010 